MARINE SHELLS OF THE CHEVERT EXPEDITION-HEDLEY.

\title{
A REVISION of the TYPES of the MARINE SHELLS of THE CHEVERT EXPEDITION.
}

By Charles Hedley, Conchologist.

(Plates xvi. - xvii.)

THE largest collection yet made of the marine mollusca of tropical Queensland, is that taken under the direction of Sir William Macleay, in 1875 , by the staff of the "Chevert," and now in the Macleay Museum, Sydney. This collection was partly described by Mr. J. Brazier in the earlier volumes of the Proceedings of the Linnean Society of New South Wales.

Later writers, who have studied the marine mollusca of this region, have failed to identify species therein described, and have complained that the account given is inadequate for recognition. ${ }^{1}$ In fairness to the Sydney Conchologist, it should be remembered that a debased style, dispensing with figures or dimensions in diagnoses, introduced by the Brothers Adams, then prevailed in London, and naturally lowered the level of work abroad.

It has resulted that recent Monographs include the names of the "Chevert" shells among the doubtful or unknown species. Where these species have been again taken, they have in several cases been described and named anew.

My intention has been to correct synonomy, and to rehabilitate neglected species. The "Chevert" novelties are treated in the order in which they were described, under the names which I consider they ought now to bear. As the drawings and measurements now given, in addition to details already published, should suffice to indicate the species, I have held redescription to be beyond the limits of this article.

I am indebted to Professors Haswell and David, custodians of the collection, for permission to examine the types and to embody the results in the present paper. To these gentlemen, and to Mr. George Masters, Curator of the Macleay Museum, my thanks are due.

\section{Drillia mastersi, Brazier.}

Drillia mastersi, Brazier, Proc. Linn. Soc. N.S.W., i., 1876, p. 153. No example of this could be found.

1 Watson-Chall. Rep., Zool., xv., 1886, p. 42, note to Puncturella, sp.; and Melvill and Standen-Journ. Linn. Soc., Zool., xxvii., 1899, p. 153. 


\section{Drillia SPALDingi, Brazier.}

(Plate xvi., fig. 1).

Drillia spaldingi, Brazier, Proc. Linn. Soc. N.S.W., i., 1876, p. 153.

The specimen figured is $14 \mathrm{~mm}$. long. It is labelled "Long Island," a locality immediately north of Bet Island. This station is not noted in the original description.

Clathurella darnleyi, Brazier.

Clathurellia darnleyi, Brazier, Proc. Linn. Soc. N.S.W., i., 1876, p. 154 .

Mangilia darnleyensis (Braz.), Tryon, Man. Conch., vi., 1884, p. 256, pl. xix., fig. 73 .

Clathurella ramsayi, Brazier.

Clathurella ramsayi, Brazier, Proc. Linn. Soc. N.S.W., i., 1876, p. 157.

No example of this could be found.

Clathurella albifuniculata, Reeve.

Clathurella albifuniculata, Reeve, Conch. Icon., i., Pleurotoma, 1846 , pl. xxviii., fig. 350 .

C. barnardi, Brazier, Proc. Linn. Soc. N.S.W., i., 1876, p. 157.

After consulting examples of $C$. albifuniculata, determined by the late Rev. J. Hervier, who so carefully studied this group, ${ }^{2} \mathrm{I}$ hold Brazier's species to be a small and dark form of Reeve's. His name might be retained for the variety. To C. albifuniculata $\mathrm{I}$ also refer Mangelia trachys, T. Woods, ${ }^{3}$ on examination of examples of the latter, collected at the original locality, compared with the type, and forwarded by Mr. J. H. Gatliff. It further seems probable that Clathurella rufozonata, Angas, ${ }^{4}$ is the same.

Clathurella macleayi, Brazier.

(Plate xvi., fig. 2).

Clathurellia macleayi, Brazier, Proc. Linn. Soc. N.S.W., i., 1876, p. 157.

The specimen figured is from Cape Grenville, and is $6 \mathrm{~mm}$. in length.

\section{Glyphostoma tricolor, Brazier.}

(Plate xvi., fig. 3).

Clathurella tricolor, Brazier, Proc. Linn. Soc. N.S.W., i., 1876, p. 158.

I have here emended Brazier's generic reference. The specimen figured is from the Palm Islands, and is $6 \mathrm{~mm}$. long. I collected this species at Milne Bay, British New Guinea.

2 Hervier-Journ. de Conch., xlv., 1897, p. 92.

3 Ten. Woods-Trans. Roy. Soc. Vict., xiv., 1877, p. 57.

4 Angas-Proc. Zool. Soc., 1877, p. 38, pl. v., fig. 14. 


\section{Murex aduncospinosus, Reeve.}

Murex aduncospinosus, Reeve, Conch. Icon., iii., 1845, Murex, pl. xxiii., sp. 93 .

Murex eximius, Brazier, Proc. Linn. Soc. N.S.W., i., 1877, p. 170.

The two individuals from Darnley Island are smaller and less thorny than Reeve's figure, but no specific differences are apparent.

\section{Murex confusus, Brazier.}

(Plate xvi., fig. 4).

Murex confusa, Brazier, Proc. Linn. Soc. N.S.W., i., 1877, p. 172.

The shell figured is from Darnley Island, and is $27 \mathrm{~mm}$. in length.

Tritonium angasi, Brazier.

Tritonium angasi, Brazier, Proc. Linn. Soc. N.S.W., i., 1877, p. 174.

No specimen of this could be found.

Marginella levigata, Brazier (emend).

(Plate xvi., fig. 5).

Marginella lavigata, Brazier, Proc. Linn. Soc. N.S.W., i., 1877, p. 225 .

? M. valida, Watson, Chall. Rep., Zool., xv., 1886, p. 267, pl. xvi., fig. 3 .

I am pretty confident that Brazier's shell was redescribed as above. One of the shells from Katow, New Guinea, $5 \mathrm{~mm}$. long, is here figured. A curious feature, not noticed in either description, is the dislocation of the parietal teeth; possibly the "Challenger's" shell, which is smaller, was not old enough to exhibit the character.

Columbella clathrata, Brazier.

(Plate xvi., fig. 6).

Columbella clathrata, Brazier, Proc. Linn. Soc. N.S.W., i., 1877, p. 229.

The example drawn is $8 \mathrm{~mm}$. in length, and from Katow, New Guinea. C. brevissima, Hervier, ${ }^{5}$ seems from the figure to resemble it.

\section{Columbella marie, Brazier.}

(Plate xvi., fig. 7).

Columbella maria, Brazier, Proc. Linn. Soc. N.S.W., i., 1877, p. 230 .

The example drawn is $10 \mathrm{~mm}$. in length, and from Hall Sound, New Guinea.

5 Hervier-Journ. de Conch., 1899, pl. lxiv., fig. 10. 


\section{Columbella moleculina, Duclos.}

(Plate xvi., fig. 8).

Columbella moleculina, Duclos, Hist. Nat. Coquilles, Columbella, 1835 , pl. ix., figs. 1, 2 ; ibid., Hervier, Journ. de Conch., xlvii., 1899 , p. 330.

Columbella inscripta, Brazier, Proc Linn. Soc. N.S.W., i., 1877, p. 230 .

The example drawn is $7 \mathrm{~mm}$. in length, and from Katow, New Guinea. I have taken this species at Port Moresby.

Columbella merita, Brazier.

(Plate xvi., fig. 9).

Columbella merita, Brazier, Proc. Linn. Soc. N.S.W., i., 1877, p. 231.

My drawings show the form and colour pattern of a shell from Darnley Island, $7 \mathrm{~mm}$. in length.

\section{Columbella pudica, Brazier.}

(Plate xvi., fig. 10).

Columbella pudica, Brazier, Proc. Linn. Soc. N.S.W., i., 1877, p. 231.

The specimen is from Darnley Island, and is $6 \mathrm{~mm}$. long.

Columbella abyssicola, Brazier.

Columbella abyssicola, Brazier, Proc. Linn. Soc. N.S. W., i., 1877, p. 232 ; ibid., Tryon, Man. Conch., v., 1883, p. 141, pl. li,, fig. 65 .

\section{Columbella læta, Brazier.}

(Plate xvi., fig. 11).

Columbella lata, Brazier, Proc. Linn. Soc. N.S.W., i., 1877, p. 232 .

The shell drawn is $4 \mathrm{~mm}$. in length, and from Darnley Island.

Turbonilla darnleyensis, Brazier.

(Plate xvi., fig. 12).

Turb̄onilla darnleyensis, Brazier, Proc. Linn. Soc. N.S.W., i., 1877, p. 257.

Odostomia (Turbonilla) dipsycha, Watson, Chall. Rep., Zool., xv., Gasteropoda, 1886, p. 494, pl. xxxii., fig. 8 .

As Watson's species was described from immature material, I have figured a more developed specimen of the "Chevert" types from Darnley Island, $6.3 \mathrm{~mm}$. in length.

Turbonilla cheverti, Hedley (nom. mut.) (Plate xvi., fig. 13).

Turbonilla eximia, Brazier, Proc. Linn. Soc. N.S.W., i., 1877, p. 257 (non T. eximia, A. Adams, Ann. Mag. Nat. Hist., (3), vi., 1860, p. 418).

The example figured is from the Percy Islands, and is $33 \mathrm{~mm}$. in length. The original name was preoccupied by Adams for a Japanese shell. 
Turbonilla aplini, Brazier.

(Plate xvi., fig. 14).

Turbonilla aplini, Brazier, Proc. Linn. Soc. N.S.W., i., 1877, p. 258.

The specimen drawn is $7 \mathrm{~mm}$. in length, and from Katow, New Guinea.

Turbonilla confusa, Brazier.

Turbonilla confusa, Brazier, Proc. Linn. Soc. N.S.W., i., 1877, p. 258.

Odostomia (Turbonilla) rhabdoides, Watson, Chall. Rep., Zool., xv., Gasteropoda, 1886, p. 492, pl. xxxii., fig. 5 .

Odontostomia clara, Brazier.

(Plate $\mathrm{x} v \mathrm{i}$, fig. 15).

Odostomia clara, Brazier, Proc. Linn. Soc. N.S.W., i., 1877, p. 259.

The shell drawn is $5.5 \mathrm{~mm}$. in length, and from Darnley Island.

Odontostomia compta, Brazier.

(Plate xvi., figs. 16, 17, 19; xvii., fig. 18).

Odostomia affinis, Brazier + O. compta, Brazier + O. polita, Brazier + O. parvula, Brazier, Proc. Linn. Soc. N.S.W., i., 1877, pp. 259, 260 (non 0. polita, Bivona nec Pease).

The shells so labelled are slight variations of one form. I have sketched 0 . affinis (fig. 17), length $5 \mathrm{~mm}$. , from Cape York; O. compta (fig. 16), length $5.5 \mathrm{~mm}$., from Darnley Island; O. polita (fig. 18), length $4 \mathrm{~mm}$., from Darnley Island; and O. parvula (tig. 19), length $3 \mathrm{~mm}$., from Darnley Island. On the box containing 0 . affinis, Brazier wrote "variety." The " $n$. sp.?" of the text seems to relate to the doubt if it differed from $O$. compta. The species is like 0. simplex, Angas, but differs by being keeled.

\section{Syrnola pulchra, Brazier.}

(Plate xvi., fig. 20).

Syrnola pulchra, Brazier, Proc. Linn. Soc. N.S.W., i., 1877, p. 261.

The type figured is decollated and plugged, it is $5.5 \mathrm{~mm}$. long, and is from Darnley Island.

\section{Eulima nitens, Brazier.}

(Plate xvii., fig. 21).

Eulima nitens, Brazier, Proc. Linn. Soc. N.S.W., i., 1877, p. 285.

The example drawn is $6.5 \mathrm{~mm}$. in length, and from Darnley Island.

Eulima amabilis, Brazier.

Eulima amabilis, Brazier, Proc. Linn. Soc. N.S.W., i., 1877, p. 285.

Eulima australasiaca, Melvill and Standen, Journ. Linn. Soc., Zool , xxvii., 1899, p. 173, pl. x., fig. 7 . 


\section{Separatista separatista, Dillwyn.}

(Plate xvii., fig. 22).

Turbo separatista, Dillwyn, Cat. Recent Shells, ii, 1817, p. 867. Trichotropis tricarinata, Brazier, Proc. Linn. Soc. N.S.W., i., 1877 , p. 313.

This species has a complicated synonymy. The first binomial application is Turbo helicoides, Gmelin, 1790, which Watson disallows,${ }^{6}$ because repeated in the same work for another shell. Since the T. helicoides, applied to $S$. separatista, has page precedence over the other, this ruling is doubtful. I follow Pilsbry ${ }^{7}$ in selecting the specific name as of Dillwyn, 1817, long prior to the name of Adams, used by Watson. The species has lately been recorded from Torres Straits by Melvill and Standen, ${ }^{8}$ who, perhaps in correction, but probably in neglect of Watson's labours, name it $S$. blainvilleana, Petit.

Brazier's specimen of S. tricarinata, $5 \mathrm{~mm}$. long, is here figured, so that if the names assembled by Watson be dispersed, this synonym may be rightly allotted.

\section{Separatista gracilenta, Brazier.}

(Plate xvii., fig. 23).

Trichotropis gracilenta, Brazier, Proc. Linn. Soc. N.S.W., i., 1877, p. 313.

The specimen drawn is $5.5 \mathrm{~mm}$. long, and is from Darnley Island. It is obvious that this, Trichotropis gabrieli, Pritchard and Gatliff, ${ }^{9}$ and $T$. torcularis, T. Woods, ${ }^{10}$ are nearly related to S. separatista. The superficial character of the untwisting of the last whorl, valued as of generic importance, fail here. It will therefore be necessary to abolish or to reform Separatista. Taking the latter course $T$. gabrieli, $T$. gracilenta, and $T$. torcularis may conveniently be distinguished from the typical northern Trichotropis, and assembled under Separatista.

\section{Ataxocerithium abbreviatum, Brazier.}

$$
\text { (Pl. xvii., fig. 24). }
$$

Cerithium abbreviatum, Brazier, Proc. Linn. Soc., N.S.W., i., 1877 , p. 316.

The shell figured is $6 \mathrm{~mm}$. long, and is from Katow, New Guinea.

The genus Ataxocerithium, to which I refer this species, was indicated by Sowerby ${ }^{11}$ and established by Tate. ${ }^{12}$ I suggest that

6 Watson-Chall. Rep, Zool., xv., 1886,p. 428.

7 Pilsbry-Cat. Mar. Moll. Japan, 1895, p. 59.

8 Melvill and Standen-Journ. Linn. Soc., Zool., xxvii., 1899, p. 169

9 Pritchard and Gatliff-Proc. Roy. Soc. Vict., 1898, p. 183 , pl xx., fig. 7.

10 Hedley-Rec. Aust. Mus., iv., 1901, p. 22, fig. 2.

11 Sowerby-Conch. Icon., xv., 1865, Cerithium, sp. 146

12 Tate-Proc. Roy. Soc. N.S.W., xxxii , 1894, p. 179. 
the unrecognised $C$. tubulus, Dunker, ${ }^{13}$ from Bass Straits belongs to this genus, and, further, that it is probably synonymous with $A$. serotinum $=A$. rhodostoma. So arranged the genus would contain two recent and one fossil species.

Cerithium bicanaliferum, Brazier.

(Pl. xvii., fig. 25).

Cerithium bicanaliferum, Brazier, Proc. Linn. Soc. N.S.W., i., 1877 , p. 317.

The shell drawn is $10 \mathrm{~mm}$. in length, and is from Darnley Island.

Cerithium elegantissimum, Hedley.

Cerithium minimum, Brazier, Proc. Linn. Soc. N.S.W., i., 1877, p. 317 (non C. minimum, Hutton, Cat. Mar. Moll. New Zealand, 1873, p. 27); C. elegantissimum, Hedley, Aust. Mus. Mem., iii., 1899, p. 436, fig. 24 (March); Bittium torresiense, Melvill and Standen, Journ. Linn. Soc., Zool., xxvii., 1899, p. 168, pl. x., fig. 6 (July).

Rissoina efficata, Brazier.

(Pl. xvii., fig. 26).

Rissoina efficata, Brazier, Proc. Linn. Soc. N.S.W., i., 1877, p. 366.

R. semisculpta, Tate, Trans. Roy. Soc. S.A., xxiii., 1899, p. 241, pl. vii., fig. 10.

To support the above synonomy I have drawn one of Brazier's types from the Barnard Islands; the decollated shell is $8 \mathrm{~mm}$. long.

Rissoina, teres Brazier.

(Pl. xvii., fig. 27).

Rissoina teres, Brazier, Proc. Linn. Soc. N.S.W., i., 1877, p. 367.

The specimen drawn is from Katow, and is $7 \mathrm{~mm}$. in length.

Rissoina pulchella, Brazier.

Rissoina pulchella, Brazier, Proc. Linn. Soc. N.S.W., i., 1877, p. 367.

R. honoluluensis, Watson, Chall. Rep., Zool., xv., 1886, p. 619, pl. xlvi., fig. 9.

Rissoina ineruis, Brazier.

(Pl. xvii., fig. 28).

Rissoina inermis, Brazier, Proc. Linn. Soc. N.S.W., i., 1877, p. 367 .

The example drawn is $5.5 \mathrm{~mm}$. in length, and is from Darnley Island.

Rissoina Cardinalis, Brazier.

Rissoina cardinalis, Brazier, Proc. Linn. Soc. N.S.W., i., 1877, p. 368.

R. mercurialis, Watson, Chall. Rep., Zool., xv., 1886, p. 619, pl. xlvi., fig. 8 . 
Rissoina inconspicua, Brazier.

(Pl. xvii., fig. 29).

Rissoina inconspicua, Brazier, Proc Linn. Soc. N.S.W., i., 1877, p. 368 .

The decollated example figured is $2.5 \mathrm{~mm}$. in length, and from Sue Island.

\section{Euchelus granosus, Brazier.}

(Pl. xvii., fig. 30).

Clanculus granosus, Brazier, Proc. Linn. Soc. N.S.W., ii., 1877, p. 43 .

I transfer this species to Euchelus. The specimen figured is 6 $\mathrm{mm}$. in height, and from Katow.

Turcia maculata, Brazier.

Thalotıa maculata, Brazier, Proc. Linn. Soc. N.S.W., ii., 1877, p. 44.

Turcia maculata, Pilsbry, Man. Conch., xi., 1889, p. 417, pl. 67, fig. 78 .

Two shells from Port Molle, Queensland, described by Smith ${ }^{14}$ as a variety of Trochus elisus, Gould, appear from his remarks to be not that but T. maculata. Tectarius montrouzieri, Fischer, also from Torres Straits, appears to me to be a Turcia.

Stomatella stellata, Souverbie.

Stomatella stellata, Souverbie, Journ. de. Conch., 1863, p. 169, pl. v., fig. 10.

Stomatella ornata, Brazier, Proc. Linn. Soc. N.S.W., ii., 1877, p. 47.

The above rectification was made by Pilsbry, ${ }^{15}$ and I can confirm it.

Dentalium duodecimcostatum, Brazier.

(Pl. xvii., fig. 31).

Dentalium duodecimcostatum, Brazier, Proc. Linn. Soc. N.S.W., ii., 1877 , p. 56.

The specimen figured is from Darnley Island, and is $21 \mathrm{~mm}$. in length.

Dentalium robustum, Brazier.

(Pl. xvii., fig. 32).

Dentalium robustum, Brazier, Proc. Linn. Soc. N.S.W., ii., 1877, p. 56.

The specimen drawn is from Katow, and is $21 \mathrm{~mm}$. in length.

14 Smith-Zool. Col. Alert., 1884, p. 74.

15 Pilsbry-Man. Conch., xii., 1890, p. 26 
Dentalium, Katowense, Brazier.

(Pl. xvii., fig. 33).

Dentalium katowense, Brazier, Proc. Linn. Soc. N.S.W., ii., 1877, p. 156.

The specimen drawn is $15 \mathrm{~mm}$. in length, and from Katow.

Dentalium cheveeti, Sharp and Pilsbry.

(Pl. xvii., fig. 34).

Dentalium septemcostatum, Brazier, Proc. Linn. Soc. N.S.W., ii., 1877 , p. 57 (non D. septemcostatum, Abich, Bull. Soc. Nat., Moscow, xxxii., 1859, p. 314, pi. vi., fig. 5).

D. cheverti, Sharp and Pilsbry, Man. Conch., xvii., 1897, p. 9 (nom. mut.)

The specimen drawn is $15 \mathrm{~mm}$. in length and from Cape York.

Dentalium quadricostatum, Brazier.

(Pl. xvii., fig. 35).

Dentalium quadricostatum, Brazier, Proc. Linn. Soc. N.S.W., ii., 1877, p. 58.

The specimen figured is from Katow, and is $16 \mathrm{~mm}$. in length. There are in the Australian Museum specimens from Cape Sidmouth, Queensland, collected from anchor mud, and presented by Mr. A. U. Henn.

Dentalium, annulosum, Brazier.

(Pl. xvii., fig. 36).

Dentalium annulosum, Brazier, Proc. Linn. Soc. N.S.W., ii., 1877, p. 58.

The specimen drawn is $14 \mathrm{~mm}$. long, and is from Princess Charlotte Bay.

Cadulus lævis, Brazier.

Dentalium lave, Brazier, Proc. Linn. Soc. N.S. W., ii., 1877, p. 59.

C. laevis, Hedley, Proc. Linn. Soc. N.S.W., 1900, p. 499, pl. xxvi., fig. $8,9,10$.

Ringicula abyssicola, Brazier.

(Pl. xvii., fig. 37).

Dentalium abyssicola, Brazier, Proc. Linn. Soc N.S.W., ii., 1877, p. 78 .

The specimen drawn is $1.9 \mathrm{~mm}$. in length, and from Darnley Island:

Retusa amphizosta, Watson.

Cylichna minuta, Brazier, Proc. Linn. Soc. N.S.W., ii., 1877, p.

80 (non C. minuta, H. Adams, Proc. Zool. Soc., 1872, p. 11, pl. iii., fig. 10).

C. brazieri, Pilsbry, Man. Conch., xv., 1893, p. 315 (nom. mut.)

Utriculus amphizostus, Watson, Chall. Rep., Zool., xv., 1886, p. 652, pl. xlviii., fig. 11. 
Cylichna granosa, Brazier.

Mnestia granosa, Brazier, Proc. Linn. Soc. N.S.W., ii., 1877, p. 81. Cylichra reticulata, Watson, Chall. Rept., Zool., xv., 1886, p. 667, pl. l., fig. 2.

\section{Atys decora, Brazier.}

(Plate xvii., fig. 38).

Haminea decora, Brazier, Proc. Linn. Soc. N.S.W., ii., 1877, p. 83.

The example drawn is $6 \mathrm{~mm}$. long, and from Cape York. Judging from the Thesaurus Conchyliorum, ${ }^{16}$ size seems the only difference between this and Atys succisa, Ehrenberg.

\section{Scaphander multistriatus, Brazier.}

Scaphander multistriata, Brazier, Proc. Linn. Soc. N.S.W., ii, 1877 , p. 84 ; ibid., Hedley, Proc. Linn. Soc. N.S.W., xxv., 1900 , p. 510 , pl. xxvi., fig. 12.

I am now inclined to refer this species to Bellandi's genus Sabatia.

\section{Atys darnleyensis, Brazier.}

(Plate xvii., fig. 39).

Atys darnleyensis, Brazier, Proc. Linn. Soc. N.S.W., ii., 1877, p. 85.

The example figured is $13 \mathrm{~mm}$. in length, and from Darnley Island. The young shells are of a different contour, and I consider that Atys hyalina, Watson, was based upon an immature $A$. darnleyensis.

\section{Atys cheverti, Brazier.}

(Pl. xvii., fig. 40).

Atys cheverti, Brazier, Proc. Linn. Soc. N.S.W., ii., 1877, p. 85.

The specimen figured is from Darnley Island, and $5 \mathrm{~mm}$. in length.

Cylichna pulchra, Brazier.

Atys pulchra, Brazier, Proc. Linn. Soc. N.S.W., ii., 1877, p. 86. Cylichna subreticulota, Watson, Chall. Rep., Zool., xv., 1886, p. 668 , pl. l., fig. 3 .

The difference between these two descriptions appears to me to be the difference between old and young shells.

Cylichna Densa, Brazier.

Atys densa, Brazier, Proc. Linn. Soc. N.S.W., ii., 1877, p. 86.

No example found.

Crlichna dubiosa, Brazier.

Atys dubiosa, Brazier, Proc. Linn. Soc. N.S.W., ii., 1877, p. 86 .

Cylichna labiata, Watson, Chall. Rep., Zool., xv., 1886, p. 669, pl. l., fig. 4.

\footnotetext{
${ }^{6}$ A. Adams-Thes. Conch., ii., 1855, pl. exxv , fig: 116.
} 


\section{$2 \mathrm{BHL}$ Biodiversity Heritage Library}

Hedley, Charles. 1901. "A revision of the types of the marine shells of the Chevert Expedition." Records of the Australian Museum 4, 121-130. https://doi.org/10.3853/j.0067-1975.4.1901.1087.

View This Item Online: https://www.biodiversitylibrary.org/item/31165

DOI: https://doi.org/10.3853/j.0067-1975.4.1901.1087

Permalink: https://www.biodiversitylibrary.org/partpdf/3510

\section{Holding Institution}

Harvard University, Museum of Comparative Zoology, Ernst Mayr Library

\section{Sponsored by}

Harvard University, Museum of Comparative Zoology, Ernst Mayr Library

\section{Copyright \& Reuse}

Copyright Status: NOT_IN_COPYRIGHT

This document was created from content at the Biodiversity Heritage Library, the world's largest open access digital library for biodiversity literature and archives. Visit BHL at https://www.biodiversitylibrary.org. 